\title{
THE LOGIC OF CERAMIC TECHNOLOGY IN MARGINAL ENVIRONMENTS: IMPLICATIONS FOR MOBILE LIFE
}

\author{
Camilla Sturm, Julia K. Clark, and Loukas Barton
}

\begin{abstract}
Explanations for the use of pots as practical domestic tools permeate the literature of technological adoption and change. While many arguments focus on the economic merits of pots, few have attempted to trace the conditions that promote or deter the adoption of pottery. This is especially true for the use of pottery by mobile peoples. We adapt an established model of technological investment to draw attention to three key variables affecting pottery adoption: manufacturing time, utility, and use time. We use the logic of this model to examine how social and environmental contexts, specifically residential mobility in marginal environments, impacts use of and investment in ceramic technology. We further illustrate how the model can be used to reveal seasonal patterns of behavior from the spatial distribution of pottery discarded by mobile foragers and herders.
\end{abstract}

Las explicaciones sobre el uso de contenedores cerámicos como herramientas domésticas utilitarias impregnan la literatura sobre la adopción y cambio tecnológico. Mientras que la mayor parte de los argumentos destacan los méritos económicos de las cerámicas, pocos han intentado rastrear los condicionantes que favorecen o desalientan la adopción de la cerámica. Esto es especialmente cierto en el contexto del uso de cerámica por parte de grupos humanos móviles. A continuación adaptamos un conocido modelo de inversión tecnológica para llamar la atención sobre tres variables clave que afectan a la adopción de la cerámica como tecnología: el tiempo de manufactura, la utilidad y el tiempo de uso. Utilizamos la lógica de este modelo para examinar cómo los contextos sociales y ambientales, específicamente la movilidad residencial en medioambientes marginales, influyen en el uso y la inversión en tecnología cerámica. Luego mostramos cómo este modelo puede ser utilizado para revelar patrones de comportamiento estacional a partir de la distribución espacial de cerámicas desechadas por cazadoresrecolectores y pastores.

$\mathrm{T}$

The archaeological study of ceramics ranges from the origins of the technology (Barnett and Hoopes 1995; Brown 1989; Garraty 2011; Jordan and Zvelebil 2009; Keally et al. 2004; Rice 1996, 1999; Rocek 2013) to the social, political, symbolic, and economic implications of change in ceramic assemblages (Clark and Blake 1994; Crown and Wills 1995; Eerkens 2004; Hayden 1995; Skibo and Feinman 1999; Vitelli 1989). Underlying each of these efforts is the assumption that people made pottery to meet the needs and desires of their communities and that variations in pottery reflect change in these objectives.

Increasingly, archaeologists are focusing on pottery production and use among mobile groups (i.e., non-sedentary foragers and herders; Eerkens
2003, 2008, 2011; Frink and Harry 2008; Gibbs 2012; Gibbs and Jordan 2013; Harry and Frink 2009; Hoopes 1995; Reid 1989; Sassaman 1993; Simms et al. 1997; Skibo et al. 2008). The discovery of early pottery at hunter-gatherer sites in southern China, Japan, and the Russian Far East dating from roughly $18,000-15,500$ B.P. reveals that ceramic technology was first developed by non-sedentary, non-agricultural peoples (Boaretto et al. 2009; Jordan and Zvelebil 2009; Keally et al. 2004; Wu et al. 2012). The invention and, more importantly, widespread adoption of ceramic technology have been explained in terms of economic utility. Pottery allows otherwise low-return resources like seeds, shellfish, and bones to be exploited more efficiently; its adoption would have

Camilla Sturm and Loukas Barton - Department of Anthropology, University of Pittsburgh, Pittsburgh, PA 15260 (cak95@pitt.edu, corresponding author)

Julia K. Clark American Center for Mongolian Studies, Ulaanbaatar, Mongolia 14251

American Antiquity 81(4), 2016, pp. 645-663

Copyright (C) 2016 by the Society for American Archaeology

DOI: $10.7183 / 0002-7316.81 .4 .645$ 
allowed groups to occupy environments where higher ranked and easier-to-process resources were scarce (Bettinger et al. 1994; Craig et al. 2013; Garraty 2011; Goodyear 1988; Ikawa-Smith 1976; Taché and Craig 2015). These explanations are supported by residue analyses, which have identified shellfish and wild starch remains in early pottery vessels from Incipient Jomon sites in Japan and Thule period sites in Alaska (Craig et al. 2013; Farrell et al. 2014).

Despite growing interest in the pre-agricultural origins of pottery, the fact remains that adoption of ceramic technology by mobile groups was patchy (Arnold 1985; Driver and Massey 1957). The archaeological record reveals that in some instances, mobile people developed and used ceramic technology for thousands of years, while in others, pottery was known but not adopted (Garraty 2011; Rocek 2013). To understand this pattern of pottery adoption among mobile foragers and herders requires that the contexts in which they appear be studied systematically. This paper contributes toward this goal by investigating the connection between economic practice, environmental context, and technological decision-making. The approach we present here helps to clarify the conditions that impact pottery adoption among foragers and herders and highlights the role of economy and technological adaptation in cultural evolution.

Pottery may have helped mobile groups exploit a broader range of resources, but its adoption was not without cost. Archaeologists cite three major ways that pottery production and use conflict with mobile lifestyles (Arnold 1985:109-126; Eerkens 2003, 2008; Gibbs 2012; Simms et al. 1997). First, pots are cumbersome to carry and are increasingly at risk of breaking with each additional move groups make. Second, the timing of pottery production may conflict with and reduce opportunities for harvesting and processing key resources. And third, how frequently groups move may limit access to adequate raw materials and sufficient time to form, finish, and fire pots. Mobile groups that adopted pottery overcame these obstacles in a number of ways. Eerkens $(2003,2008)$ suggests that groups cached pots in places where they were needed for seasonal processing tasks instead of transporting pots on seasonal moves. Alternatively, potters modified vessels with lugs or specialized handles to make carrying them easier and less unwieldy (Arnold 1985:110). Others have instead argued that mobile potters produced cheap, expedient pots that they discarded immediately after use (Gibbs 2012; Simms et al. 1997). Beck (2009) documents several cases in which mobile people acquired their pottery from neighboring sedentary groups to limit production costs. Of course, some mobile groups never used pots at all, preferring to use organic containers like baskets, skin bags, or wooden vessels for cooking (Speth 2015).

These discussions have drawn attention to the many ways that people modify ceramic technology to suit mobile lifestyles. However, few researchers have attempted to explain the logic underlying these modifications and why they were adopted often enough to generate recognizable patterns in the archaeological record. In this paper, we use a rational economic model of technological investment to characterize the conditions under which mobile people devote time and labor to producing pottery. We examine how the practice of residential mobility in marginal environments affects decisions about the production and use of pottery. Here we use marginal to refer to continental, terrestrial landscapes marked by strong seasonal and interannual variations in temperature, precipitation, and biomass availability. When the resulting food supply also varies from season to season and from year to year, shortfalls are inevitable and potentially devastating. In such contexts, human adaptive strategies (including various combinations of technology, patterns of residential movement, and exploitation of different resources) evolve to manage food supply volatility. Our goal is to understand how environmental factors interact with human settlement and subsistence strategies to influence decisions about investment in pottery. These are not the only factors that influence investments in ceramic technology, but because they are often visible in the archives of the past, they provide a baseline for developing initial hypotheses about technological adoption and change.

The first section of this paper reviews a formal model of technological investment and intensification (Bettinger et al. 2006; Ugan et al. 2003). We present two general cases involving change in container technologies to illustrate how the model works and how it can clarify interpretations of technological decision-making. We then return 
to the issue of pottery and mobility to outline several features of forager and herder lifestyles that constrain or encourage investments in pottery technology, particularly in marginal environments. Finally, we apply the model to two contexts of residential mobility in marginal environments to generate expectations about spatial patterns of pottery distribution on a hypothetical regional landscape. These hypotheses can and should be tested in future studies to refine our understanding of regional patterns of human mobility, site seasonality, and resource use, particularly in contexts where ceramics feature prominently in archaeological assemblages.

\section{The Technological Investment Model}

The technological investment model is derived from optimization models in foraging theory, particularly the Marginal Value Theorem (Charnov 1976). It was first described by Bright et al. (2002), mathematically formalized by Ugan et al. (2003), and further refined by Bettinger et al. (2006). The model addresses decisions that drive technological change by comparing two or more technological variants in light of the interactions among three simple variables: the time required to manufacture the variant, the utility of the variant, and the amount of time the variant will be used (Ugan et al. 2003: 1315). Recent applications of the model have been used to identify and investigate patterns of technological change and raw material procurement in lithics (Bettinger et al. 2015; Garvey 2015).

The central premise of the tech investment model is that the amount of time one devotes to manufacturing a tool is related to both the amount of time one expects to use it and the amount of utility or benefit one expects to receive from it. Technologies that offer high returns but are more expensive to produce will replace cheaper, less productive technologies when they are used long enough to offset the cost of their manufacture.

The first component of the model, manufacturing time $(m)$, refers to the total amount of time one spends making a tool (Figure 1). In the case of pottery, this includes time spent collecting and processing clay and temper, forming vessels, investing in decoration, gathering fuel for firing, and firing vessels. Any span of time that a potter is not actively engaged in producing a vessel, as when pots are allowed to dry, is excluded from manufacture time. The second component, use time $(v)$, refers to the length of time that a finished pot is used to process, store, or serve food, and is measured in the same unit as manufacturing time. Unless pots also serve as carrying vessels for food or other goods during moves, transit time should not be included in use time. The final component, utility $(f(m))$, is a measure of technological productivity that is most often expressed in terms of energy per unit time ( $\mathrm{kcal} / \mathrm{hr}$ ), which itself is justified for its long-term relevance to survival and reproduction. While it is possible for utility to reflect more complex measures such as social capital or political influence, in this paper, we define utility as the rate of calories made available to consumers for every hour the vessel is in active use. As a result, our discussion is directly relevant to utilitarian cooking and storage vessels that are used to meet basic energetic requirements. Each of the components in this model (manufacturing, utility, and use) is subject to a series of constraints specific to the context of application, which we discuss in some detail below.

Graphically, the tech investment model is illustrated with use time and manufacturing time on the $\mathrm{x}$-axis to the left and the right of the $\mathrm{y}$ axis, respectively, and utility on the $y$-axis (Figure 1). In the example in Figure 1, competing technologies "A" and "B" are plotted on the basis of their manufacturing time $\left(m_{A}\right.$ and $\left.m_{B}\right)$ and utility $\left(f\left(m_{A}\right)\right.$ and $\left.f\left(m_{B}\right)\right)$. In the original version of the model (Ugan et al. 2003), technological variants were drawn along the same utility curve, implying that they provided users with a constant rate of return as indicated by the slope of the gain function, or the increase in utility provided by each unit of increase in manufacturing time (Figure 1a). This limits the scope of technological comparison to variants within a single category of technology, such as dollar-store frying pans and professional-grade frying pans. We instead adopt the amended version of the model (Bettinger et al. 2006), which conceives of each variant as having its own utility curve (which can be estimated by single data points) and thus as independent of the other (Figure 1b). This "point-estimate" approach is more flexible than the original because it allows comparisons to be made within a single 


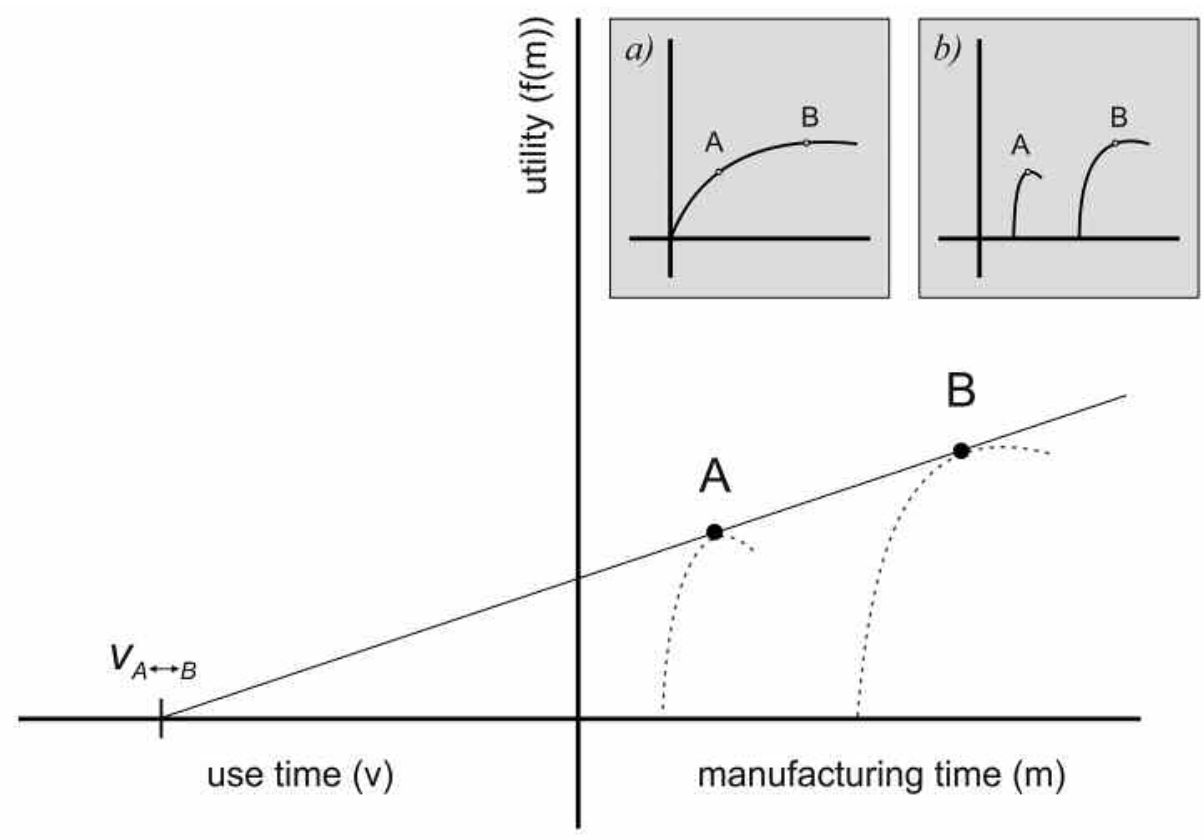

Figure 1. Point-estimate model determining the use-time threshold at which a rational economic actor will switch between technological variants, $A$ and $B$. For periods of use between $\mathrm{v}=0$ and $\mathrm{v}=v_{A \leftrightarrow B}$, technology $A$ provides users with a higher rate of return and will be preferred over technology $B$. For use times longer than $v=v_{A \leftrightarrow B}$ (to its left), however, technology $B$ offers users with a higher rate of return, displacing technology $A$. We followed Bettinger et al. (2006) in considering technological alternatives as having independent gain functions (1b) rather than sharing a single gain function (1a).

technological category (more and less expensive frying pans) as well as between completely different technologies with a common application (a compass and a hand-held GPS unit).

One of the advantages of the tech investment model is that it accounts for use time in predictions for investment. Intense users of a technology will reach a point when it becomes worthwhile to invest in a more expensive, efficient tool over a quick, cheap alternative. This threshold is referred to as the "critical use time" $\left(v_{A \leftrightarrow B}\right)$ and is defined as the amount of use time at which the benefits provided by two technological variants are equivalent. In Figure 1, critical use time is depicted as the $\mathrm{x}$-intercept of line $\mathrm{AB}$. For periods of use shorter than $v_{A \leftrightarrow B}$, cheap technology A provides a higher return rate (utility per unit time spent manufacturing) and should be favored. For use times longer than $v_{A \leftrightarrow B}$, expensive technology B provides a higher return rate and should be favored.

To be competitive, modeled variants must meet two basic conditions. First, the expensive variant must provide greater utility than the cheap variant $\left(m_{B}>m_{A}\right.$ and $f\left(\left(m_{B}\right)>f\left(m_{A}\right)\right)$. To the rational actor, an expensive, inefficient technology is never vi- able in the face of a cheaper, more productive alternative. Second, the cheap variant must provide a gain in utility per increase in manufacturing time equal or higher to that provided by the expensive variant

$$
\left(\frac{f\left(m_{A}\right)}{m_{A}} \geq \frac{f\left(m_{B}\right)}{m_{B}}\right) .
$$

The favored variant will be that which provides users with higher utility returns across its lifespan (i.e., from manufacture to final discard),

$$
\frac{f(m)}{m+v} \text {. }
$$

As with other behavioral economic models, the tech investment model assumes humans to be rational economic actors. We do not deny that individuals make decisions for a myriad of complex reasons beyond the desire to maximize fitness or utility gains. However, we argue that rational actor models of decision-making capture human behavior in the aggregate, and, more importantly, that such simplicity is what makes models powerful heuristic devices for generating explicit, 


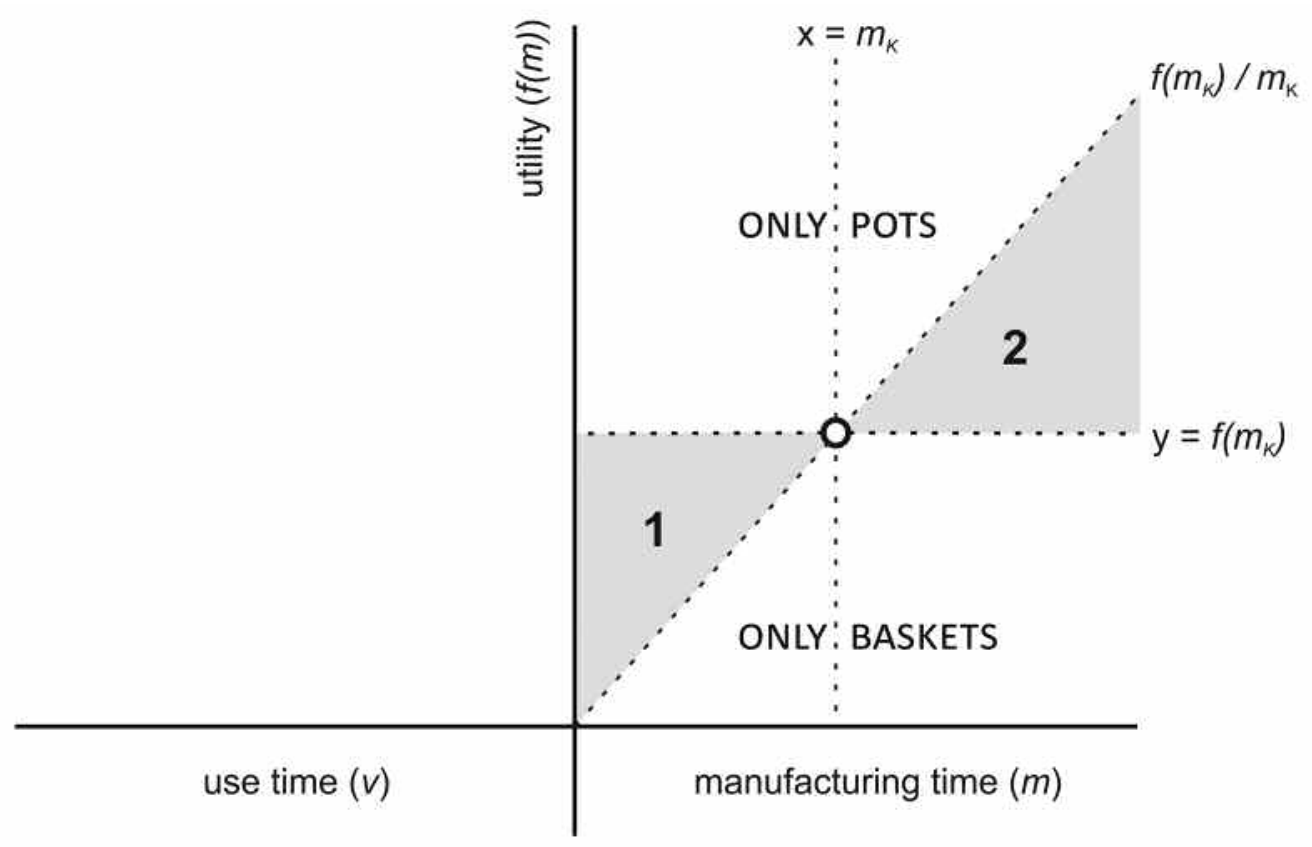

Figure 2. Range of potential technology comparisons for baskets (open circle) and pottery (any point with positive values of $m$ and $f(m)$ ). These container technologies are competitive when values for pottery manufacturing and utility fall within the shaded areas marked 1 and 2 . Under these circumstances, the decision to invest in one technology over the other is informed by expected use time.

testable hypotheses. This is especially true for the large time scale and coarse resolution at which individual decisions are usually registered in the archaeological record.

The model does not predict invention. Rather, it predicts which of two or more preexisting technologies a rational actor will adopt under a particular set of social, economic, and environmental parameters. As these parameters shift, they affect which technological variants are adopted and ultimately recovered from archaeological contexts. In this way, the logic of the tech investment model can be used as a framework for understanding the appearance, disappearance, and replacement of technological variants such as pottery.

We use two examples of technological change to show how the logic of the tech investment model can help to explain the adoption and use of pottery. The first example, a comparison across technological classes, highlights conditions that would foster the adoption of basketry or pottery cooking vessels. The second example focuses within a single class of technology to identify conditions that support the adoption of low- and high- investment pottery. Both issues are more commonly referenced in the literature of mobile pottery producers, but are relevant to studies of pottery adoption and intensification among sedentary groups as well.

\section{Basketry and Pottery}

Pottery is often portrayed as a technological advance over organic cooking containers: it is highly plastic when wet, sturdy when fired, and is able to withstand long periods of exposure to direct heat without supervision (Arnold 1985; Brown 1989; Crown and Wills 1995; Rice 1999). Yet, there are several examples of societies that are aware of ceramic technology but do not adopt it, opting instead to prepare and cook foods with baskets or other organic containers (Driver and Massey 1957: 245-247; Rocek 2013; Speth 2015; Thoms 2009). Here we explore the general reasoning behind this phenomenon.

We use the tech investment model in Figure 2 to highlight combinations of variables that foster production and use of only pottery, of only basketry, and of a mixture of the two technologies. 
As we are interested in exploring these three scenarios conceptually, this discussion focuses on the relative placement of these technologies and not on actual manufacturing, utility, or use-time data.

Using global ethnographic data, Nelson (2010) identified a persistent relationship between container technologies and cooking methods in which pottery vessels are most often used in direct-heat cooking, and bark and basket containers are more widely used in indirect-heat cooking (Nelson 2010; Thoms 2009; but see Speth 2015). Following these observations, Figure 2 also depicts the conditions that make direct-heat cooking (of the kind one might do with a ceramic vessel) more advantageous than indirect-heat cooking (that one might do with a basket), or vice-versa.

The first variable that affects the adoption of cooking container technologies is utility. Directheat cooking provides greater returns in contexts where scheduling conflicts, fuel scarcity, and environmental uncertainty are common (Braun 1983; Crown and Wills 1995; Nelson 2010). Simmering foods directly over a fire allows cooks to multitask, which may be especially valuable in regions with marked seasons or in communities with a limited labor pool (Crown and Wills 1995; IkawaSmith 1976:514; Sassaman 1993). Second, direct boiling requires less fuel than indirect boiling, making it a more efficient cooking strategy in areas where fuel is scarce or the timing and degree of rainfall are unpredictable (Braun 1983; Harry and Frink 2009; Nelson 2010). Long, slow cooking is needed to detoxify nuts and legumes, to extract fat from bone (i.e., "degreasing"), and for processing plants and small seeds that are otherwise labor intensive to prepare (Goodyear 1988; Hoopes 1995; Ikawa-Smith 1976). We expect pottery to be the prevalent type of cooking container used where direct-heat cooking provides greater utility than indirect-heat cooking (Figure 2). On the other hand, indirect heating, particularly hot-rock cooking, provides greater returns in temperate and boreal environments where rainfall and fuel are both abundant and predictable (Nelson 2010). Hot-rock boiling requires more labor and fuel than directheat boiling (Harry and Frink 2009), and thus may be better suited to prepare foods that require only short cooking times, as in parboiling high-quality meat (Frink and Harry 2008; Thoms 2009; Wandsnider 1997). Heating and holding the temperature of cooking rocks is less costly in wet environments where fuel burns more slowly and consistently than in arid regions (Nelson 2010). Indirect heating is less effective in cold environments, as heated rocks lose energy when they are moved from the fire to the cooking container (Nelson 2010). Indirect-heat cooking is more common where rainfall and fuel are abundant, and foods require shorter cooking times. All else being equal, organic cooking vessels such as baskets are expected to provide greater utility in these regions than are ceramic cooking vessels. Under such circumstances, the use of baskets may completely displace the use of pots (Figure 2).

Changes in manufacturing time will also impact investment in one container technology over the other. Manufacturing costs are affected by two primary factors: the availability of raw materials and the scale of production. Access to suitable resources and the necessary skillsets to produce baskets or pots will shorten manufacturing times, while geographical or sociopolitical boundaries may limit access to basketry materials, clay, or fuel, and thus increase manufacturing times.

The volume of vessels that can be produced at one time also impacts manufacturing costs. It has been argued that pottery production is more readily scaled than basketry (i.e., as production volume increases, the average cost per unit decreases; Brown 1989; Crown and Wills 1995); however, techniques such as coppicing also may increase the scalability of basket production (Anderson 1999). If and when groups aggregate may also encourage the use of a particular container type.

Finally, under certain conditions, baskets and pottery are mutually viable, competitive technologies (Figure 2, zones 1 and 2). If manufacturing time and utility values for pots fall in zone 1, pottery will offer greater returns when used for shorter periods of time than baskets. Alternatively, if values for pots fall in zone 2, pottery is more costly to manufacture than basketry, but offers greater returns when used for longer periods of time.

Rainfall and climate are by no means the only factors that influence decisions to invest in one container technology over the other. Yet even such basic data can be used to develop testable hypotheses about the appearance of distinct forms of material culture. The disappearance of pottery 
from the archaeological record may indicate that changes in access to resources, local cuisine, or labor systems have shifted the costs and benefits of investment in favor of organic cooking vessels.

\section{Expedient and Curated Pottery}

In the previous example, we used the tech investment model to demonstrate how factors affecting the utility and manufacturing costs of two different categories of container technology can influence their adoption. Even among variants of the same technological category, manufacturing costs may differ significantly. Here we explore how changes in manufacturing time, utility, and use time impact the adoption of two variants of the same technological category: low-investment and high-investment pottery. We contend that these variables feature prominently in decisions about pottery use among mobile groups, and that understanding these variables will help to reveal the behavioral dimensions behind the archaeological patterning of ceramic wares.

A major impediment to the adoption of pottery by mobile groups is transport (Eerkens 2008, 2011; Gibbs 2012; Gibbs and Jordan 2013; Jordan and Zvelebil 2009; Rocek 2013; Simms et al. 1997). Gibbs (2012) and Gibbs and Jordan (2013) have argued that one way mobile people avoided transporting pots on seasonal rounds was by producing cheap pottery vessels when and where they were needed and discarding them after use and prior to moving. Low-investment ceramic technology is comparable to expedient, situational lithic technology (Binford 1979), produced with minimal effort when their application is known, and with whatever raw materials are available locally (Andrefsky 1994). Expedient, low-investment pottery contrasts with curated, high-investment pottery that is transported between seasonal residential camps and may be multi-functional. Curated pottery is akin to curated lithic tools (sensu Binford 1979), which are designed to provide reliable, repeated use under unpredictable conditions, and are manufactured with consideration for raw material quality and performance. For pots to be "curated," they must be able to withstand repeated, extended use; in a word, curated pots must be durable. We use the tech investment model to outline conditions in which people are likely to rely on high- versus low-investment pottery.
We consider low-investment pottery to be made from the nearest available clays, shaped with little care for the finished form, and fired for as short a period as will permit the vessel to fulfill its intended purpose. By contrast, we consider highinvestment pottery to be made from a preferred clay source or tempered to become more workable, reduce shrinkage, and increase resistance to thermal shock; shaped with some final form in mind; and fired in a way that is designed to maximize the vessel's strength. High-investment pots may also exhibit some surface treatment like smoothing, burnishing, or scraping, which may enhance utility. There are several ways of differentiating between high- and low-investment pots in the archaeological record. In northern Mongolia, for example, we have found the angularity, quantity, and sorting of inclusions in clay pastes to be a useful marker of the addition of temper, which is one way we have found to distinguish expedient pottery (no added temper) from curated wares (temper added; see also Rice 2015:86-88). Other methods include Feinman et al.'s (1981) production step measure, an ordinal scale index of the labor costs of ceramic manufacture, as well as the application of geochemical or petrographic analyses to identify raw material sources and calculate the costs of their acquisition (e.g., Blackman et al. 1989; Hall et al. 1999; Jorge et al. 2013). We stress that whether pottery is characterized as "low" or "high" investment is context specific, and what may be considered expedient production in one region may in fact involve significant amounts of labor in another (Frink and Harry 2008). The actual manufacturing times and utilities of expedient and curated pottery will differ from region to region depending on the quality of available raw materials and fuel, local climates, and cultural knowledge of production techniques. Here we focus again on the relative relationship between low-investment and high-investment pottery to discuss general trends in their adoption. As utilitarian pottery is our focus, we assume that any additional investment in manufacturing is intended to increase the utility or extend the uselife of vessels.

Figure 3 captures the relationship of a low-investment, expedient pot with a high-investment, curated pot. Graphically, a low-investment pot can occupy one of three zones: zone A, zone B, 


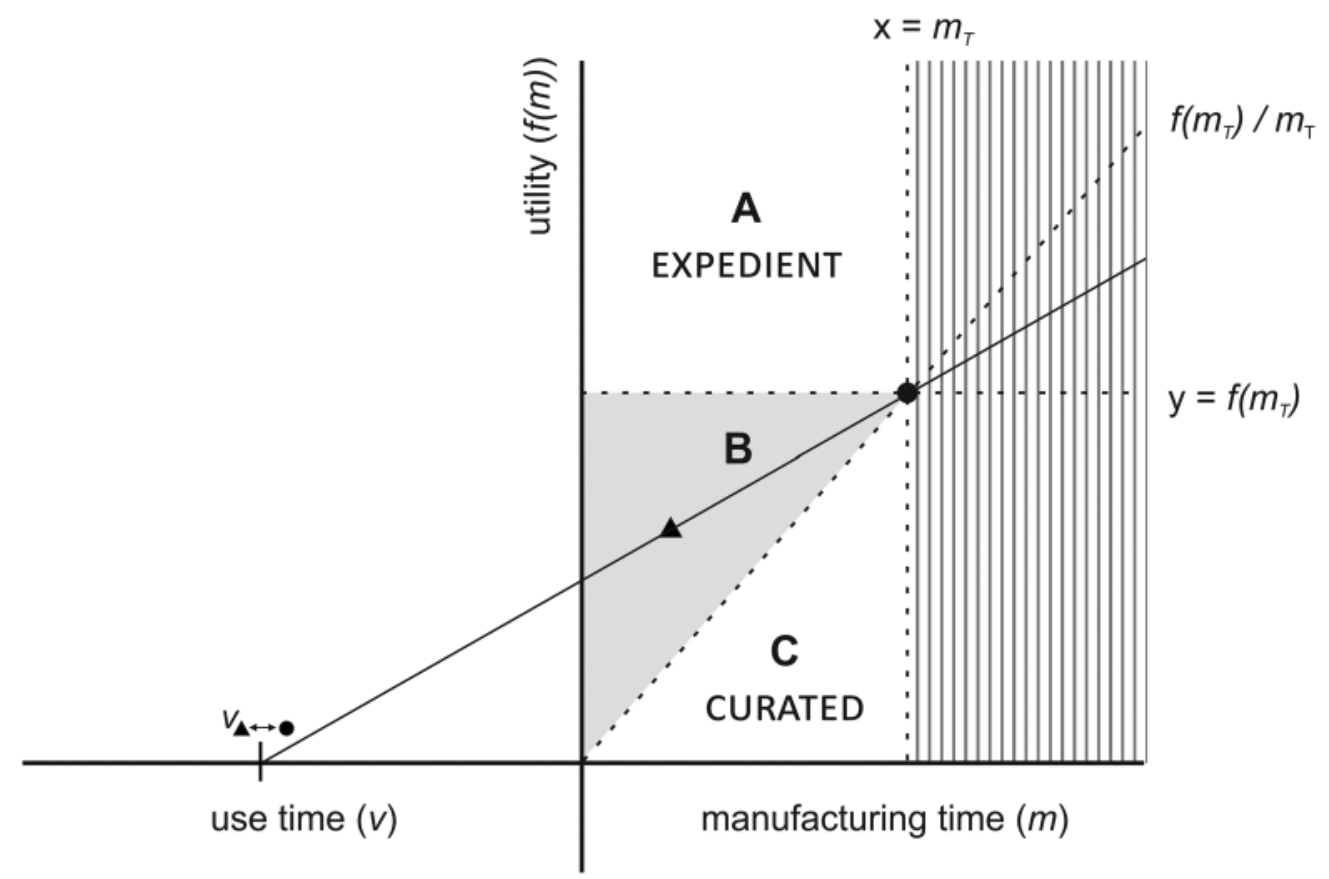

Figure 3. Range of potential technology comparisons for high-investment pottery (closed circle) and low-investment pottery (any point with positive values $\boldsymbol{m}$ and $f(m)$, where $\boldsymbol{m}<\boldsymbol{m}_{T}$. Where values for low-investment pottery fall in area $\mathrm{A}$, low-investment pottery supplants high-investment pottery. Where values for low-investment pottery fall in area $\mathrm{C}$, highinvestment pottery replaces low-investment pottery. Both pottery variants are competitive only in area $\mathrm{B}$, where the decision to invest in one or the other is determined by the length of time the user anticipates using the vessel. For periods of use shorter than $v_{\Delta \leftrightarrow \bullet}$, low-investment pots are favored, whereas for use longer than $v_{\Delta \leftrightarrow \bullet}$, high-investment pots are favored.

or zone $\mathrm{C}$, each of which has lower manufacturing times than the high-investment pot.

In cases where the use of low-investment pots provides greater utility than high-investment pots, potters are likely to place a low value on durability and may only make expedient vessels (zone A, Figure 3). This may occur in regions where premium potting clay is abundant and where investing more time refining vessels does not improve their performance. This situation might also emerge when pots are mass-produced. The adoption of technologies of scale, like kilns and the fast-wheel, can produce conditions that make it more efficient to use and dispose of low-investment, poor-quality vessels than it is to invest in producing higher-quality, labor-intensive vessels. The scale of production (along with the articles of production) necessary to create these conditions is quite high, however, and would probably be extremely rare among mobile populations.

On the other hand, where low-investment pots offer lower return rates than high-investment pots (zone C, Figure 3), producers are likely to place greater emphasis on vessel durability. This may occur in places where potting clays are poor and require extensive processing to be transformed into effective tools for food preparation, storage, and possibly service. Without such investments, the advantages of cooking with these poor-quality pots may not be worth the trouble of their manufacture. Other natural factors, such as a scarcity of appropriate fuel for firing pots, may also reduce the utility returns of low-investment pottery relative to high-investment pottery.

Under limited conditions, both low-investment and high-investment pots are viable, and the decision to invest in one or the other is based on expected use time. The range of values for low-investment pottery that mark this contingency appear in zone B, Figure 3. The model predicts that for periods of use shorter than $v_{\boldsymbol{\Lambda}} \leftrightarrow \mathbf{\bullet}$, low-investment pottery will be favored, while for periods of use longer than $v_{\boldsymbol{\Delta} \leftrightarrow \mathbf{\bullet}}$, high-investment pottery will be favored. Differences in intended use time 
may reflect the various kinds of tasks pots are designed to perform. When pottery is needed to meet a specific, short-term purpose, the model predicts that producers should invest less time in manufacture. Goulder (2010), for example, has argued that expediently produced Uruk bevel-rim bowls were made to bake bread rations and were disposed of immediately after use. By contrast, potters should choose to invest more time in the production of vessels that are needed for more extended use.

Both examples that we have used to illustrate possible applications of the tech investment model to questions about pottery adoption are hypothetical. While actualistic data for manufacturing time, utility, and use are not required to study the relationships between variables, these values are available through ethnoarchaeological, historic, experimental texts, and can be easily incorporated into the model to investigate particular cases of technological change. With or without these real or near real data, the model permits clear thinking about alternative technologies and the variables that structure human decisions about which technology to use.

\section{Pottery and Mobility}

We return to the original question of pottery adoption among mobile people to focus on the features of forager and herder mobility strategies that might impact investment in ceramic technology. The practice of mobility is a social and economic strategy for retaining access to resources across seasons. Despite cursory similarities, forager and herder mobility are fundamentally different and represent distinct strategies of provisioning. There is a diversity of ethnographically and archaeologically documented patterns of mobility and resource acquisition for both foragers and herders; under certain conditions, for example when foragers adopt domestic plants or animals or when herders turn their attention wild plants and animals, these strategies may overlap considerably. However, such cases of overlap are rare, and perhaps best characterize transitional, or unstable, states. Indeed, analysis of ethnographically documented hunters and herders suggests that the two strategies are most often quite distinct in terms of mobility and technology and may therefore be mutually incompatible (Ullah et al. 2015). Our aim here is to exploit this contrast to explore how the constraints of mobility, seasonality, and scheduling influence decisions about ceramic production and use under different economic, social, and environmental regimes.

Mobility modulates how foragers and herders use ceramic technology to process, store, and serve subsistence items. Mobile groups use pottery in many of the same cooking tasks: boiling seeds, roots, and shellfish (Craig et al. 2013; Garraty 2011; Taché and Craig 2015), extracting fat from bone (Binford 1978: 159) deactivating toxic chemicals from foods like acorns (Eerkens 2004; Lewthwaite 1982; Rice 1999:9), and preparing foods for storage (Dietz and Erdman 1989; Wandsnider 1997). What separates pottery use among foragers from that of herders is that the latter use pots to exploit secondary animal products, namely dairy: herders use specialized pottery to collect and store milk, strain curd for cheese, make yogurt, and ferment milk (Copley et al. 2005; Dunne et al. 2012; Outram et al. 2009). These differences suggest that it is possible to identify differences in herder and forager land-use patterns through ceramic analysis.

Investment in ceramic production and use by mobile people is regulated by several factors, the most universal of which are climate, the seasonal availability of resources, and patterns of mobility. Access to the resources that are both used to make and to fill pots is constrained by local environments. In high-latitude or high-altitude zones, frozen ground makes mining for clay and other raw materials difficult or impossible for most of the year, and as a result, the acquisition of raw materials may only be possible during a few short months of the summer. Yet, in these same environments, pots are often essential to survival during winter months. This is because diets high in protein but low in fats or carbohydrates can cause serious illness, and because extended reliance on lean meat alone may be fatal (Speth and Spielmann 1983). Pottery makes it possible to render grease from bones when other sources of fat are inaccessible.

Resource availability and patterns of landscape use may also impact pottery adoption. Pottery is likely to be used in very different ways in contexts where resources are predictable and reliable than 
in those where resources are randomly encountered and opportunistically exploited. For example, foragers may cache pottery in valley bottoms to be used in months when wetland resources are abundant and easily harvested (e.g., Eerkens 2008). Alternatively, if groups unexpectedly come across a resource patch that they wish to exploit, they may use materials collected nearby to expediently produce vessels to process them.

The nature of seasonal moves also has implications for pottery adoption. The simplest way to minimize the risks and costs of transporting pottery is not to use it at all, or to purchase it from ceramic-producing neighbors and leave it behind (Beck 2009). Speth (2015) demonstrates that ceramic containers are not necessary to boil foods and that, in fact, the kind of long term, direct-heat cooking that archaeologists typically associate with pottery is easily accomplished in skin bags, baskets, and even paper cups. Nevertheless, the archaeological record clearly shows that mobile people around the world did use pots at various times and places (e.g., Barnett and Hoopes 1995; Jordan and Zvelebil 2009). When pots are needed only a few times a year, mobile groups may choose to cache vessels (Eerkens 2003, 2008) or produce cheap, disposable pots (Gibbs 2012; Gibbs and Jordan 2013; Simms et al. 1997) to forgo carrying vessels on seasonal rounds. Where pottery is transported, vessels may be manufactured in a way that reduces their weight and the likelihood of breakage in route (Eerkens 2003, 2008, 2011; Skibo et al. 1989; Skibo et al. 2008). This greater investment in production is conditioned by potters' expectations for future use, impressions of the risks of transport, and perceptions regarding the utility of durable ceramic containers.

In many ways, caching pots and producing durable pots are variations on a common strategy in which vessels are expected to be in use over long periods of time. The decision to employ one approach over the other is intertwined with broader perceptions of the landscape, land tenure, territoriality, notions of property, commitments to storage, and both seasonal and annual variations in resource abundance. Making expedient, disposable pots, on the other hand, represents a very different decision-making process.

If it is possible to use ceramics to interpret behavior, the reverse should also be true. In the fol- lowing section, we draw on the constraints of mobility and marginality we have outlined to make predictions about the distribution of archaeological ceramics in a hypothetical regional landscape. We use the logic of the tech investment model not only to explain changes in technology through time but also to clarify patterns of tool use across space.

\section{Tracing Settlement Patterns with the Technological Investment Model}

One way to identify patterns of mobility and seasonality in the archaeological record is to trace variation in technology at the scale of the settlement system. Though this approach is typically achieved through lithic analysis, here we illustrate that mobility and seasonality can also be traced through analysis of ceramic assemblages. To demonstrate how this may be achieved, we develop two idealized comparisons of ceramics distributed across an idealized landscape. These cases build on our previous discussion of low-investment, expedient pottery and high-investment, curated pottery and are based on expectations for ceramic use given particular dietary, behavioral, and environmental limitations of mobile forager and mobile herder groups.

The primary question these idealized cases are positioned to address is how mobile people balance the costs of transporting pottery on seasonal rounds when it is most easily made in the summer but provides greatest utility in the winter. These cases also underscore how knowledge of environmental constraints, as well as manufacturing costs, use time, and utility of pottery can be used in concert to interpret the often ephemeral remains of mobile forager and herder settlements with regards to subsistence strategies and site seasonality.

These thought experiments are based on, but do not employ, real archaeological data. By focusing on the impact of marginal environments and mobility on patterns of ceramic manufacturing time, use time, and utility, we can develop a deeper understanding of how factors affect technological investment. The patterns we describe in the foraging example might, for example, be applied to study patterns of migration and technological evolution in areas as disparate as Siberia, northern China, and the American Great Basin. Similarly, the scenario we outline for herders could be used 
to interpret to archaeological data from northern Mongolia, central Eurasia, or the Tibetan Plateau.

\section{An Idealized Case of Forager Land-Use and the Distribution of Pottery}

Our first thought experiment focuses on the spatial distribution of low- and high-investment pottery by mobile foragers living in marginal environments. This example relies on an important evolutionary dichotomy among northern latitude foragers - the switch from winter sedentism to winter mobility (Yi et al. 2013) - and we demonstrate how the abundance and distribution of ceramics might be used to differentiate between these practices.

Northern latitude foragers typically answer the challenges of winter in one of two ways. In the first strategy, foragers aggregate in winter months around stored and/or logistically acquired resources but divide into smaller groups and disperse widely to acquire resources independently during the remainder of the year. In the second strategy, foragers divide into small groups that move often to acquire mobile, dispersed prey during the winter months but aggregate in other months to engage in communal resource acquisition and craft production. The first strategy is characteristic of midlatitude foraging groups who place significant emphasis on storage, spend more time in winter camps, and move only a few times throughout the year. The second is a pattern characteristic of high-latitude foraging groups who place much less emphasis on storage, spend less time in seasonal aggregations, and move more frequently throughout the year (Binford 1980; Yi et al. 2013). Binford (1980) referred to the latter groups as "serial specialists" and saw their practices as exceptions to his "forager-collector" continuum and its environmental determinants. High-latitude foragers move often and store little, much like tropical low-latitude foragers, but also invest heavily in complex, specialized technology, much like mid-latitude foragers, albeit with technology geared toward high residential mobility and cold weather travel. This suite of complex technology requires a period of downtime and maintenance between seasonal moves for raw material acquisition and craft production (i.e., technological investment) that would encourage aggregation. Analogies of this practice include ethnographically documented "sewing camps" of the North Amer- ican Arctic and archaeological correlates identified in the Late Pleistocene of northern Asia (see Yi et al. 2013). We see winter aggregation and summer aggregation practices as fundamentally distinct and mutually exclusive solutions to the severe challenges of a northern winter. For the purpose of this example, we assume they do not coexist in time and space, but rather illustrate different approaches to similar regions or different approaches to the same region at different times.

Figure 4 depicts how the spatial distribution of ceramics might reveal these two distinct landuse strategies. These thought-experiments are based on several operating assumptions about pottery use and group dynamics. First, we assume that the number of people on the landscape is constant throughout the year, regardless of strategy, and that people aggregate during one six-month season and disperse for the remainder of the year. We also assume that raw materials are present in equal quantities across the landscape, but that due to environmental constraints pots can be made only during the summer. Finally, we assume that aside from strictly functional, utilitarian concerns, there are no cultural prohibitions on using pots in one season or another.

All else being equal, places occupied by larger numbers of people for longer periods of time ("aggregation" areas) are expected to be characterized by a high absolute abundance of artifacts relative to those places that are occupied by only a few people for shorter periods of time (short-term, task-specific camps and activity areas). Shortterm activity areas, which are characterized by low artifact densities, should outnumber aggregation areas in proportion to the degree of mobility practiced: groups that move more often will leave behind a larger number of low-density artifact scatters than groups that move less often.

Similarly, our interpretation of aggregation areas as summer or winter settlements rests on the ratio of high- to low-investment pottery and on the total abundance of pottery to other artifact classes. In this case, we use lithics to illustrate differences in the relative importance of pottery. We acknowledge that counts of lithic artifacts may vary depending on the kinds of activities practiced at each settlement as well as the length of their occupation, but for the sake of simplicity, we consider lithic deposition to be constant. 

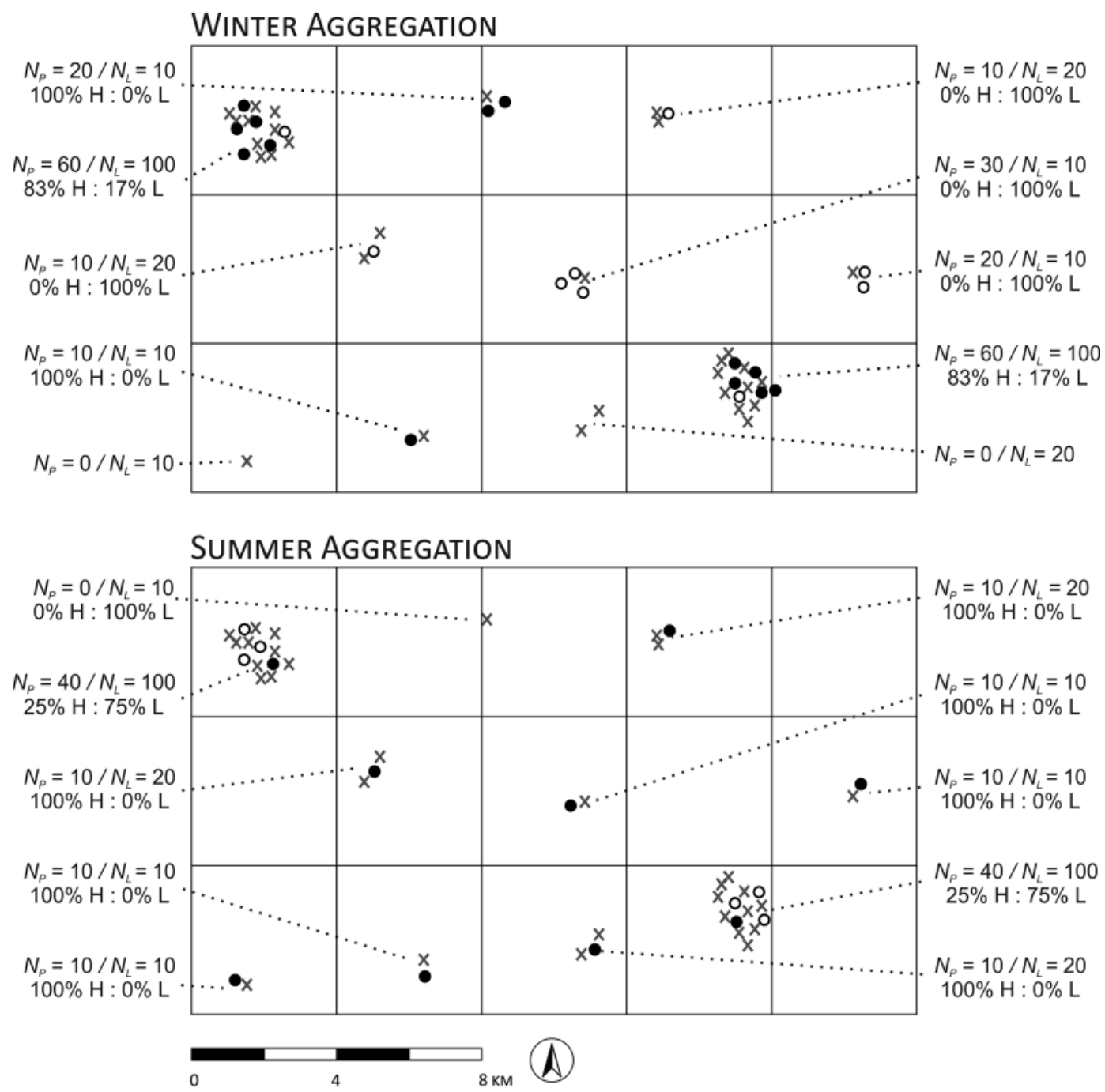
O 10 LOW-INVESTMENT SHERDS
- 10 HIGH-INVESTMENT SHERDS
$\times 10$ LITHICS
$\boldsymbol{N}_{p}$ : TOTAL POTTERY
$N_{L}$ : TOTAL LITHICS
$67 \%$ H : $33 \%$ L: \% HIGH-INVESTMENT POTtERY,

Figure 4. Idealized spatial distribution of forager ceramic and lithic remains in winter aggregation-summer dispersal (top) and summer aggregation-winter dispersal (bottom) systems in a marginal environment. Given the constraints of a marginal environments on pottery production and use, winter aggregation areas are marked by a high ratio of ceramics to lithics, and a high proportion of high-investment pottery to low-investment pottery (top). Summer camps are marked by low-density scatters of lithics and both low- and high-investment pottery. In contrast, summer aggregation areas are marked by a low ratio of ceramics to lithics, and a low proportion of high-investment to low-investment pottery. Dispersed winter camps contain low-density artifact scatters, but the ceramic assemblages of these sites are dominated by high-investment pottery. 
We expect aggregation areas marked by (1) high ratios of ceramics to lithics and (2) high proportions of high-investment, curated pots to be occupied during the winter (see "Winter Aggregation" in Figure 4). This expectation is best explained by reference to the tech investment model: given the constraints of ceramic production in marginal environments, foragers likely get the greatest utility out of pottery during the cold months in extracting essential lipids from animal bone when vegetation is scarce and animals are lean (Speth and Spielmann 1983). Pots would be needed to fulfill this critical task for extended periods of time and, following the model logic, would thus merit greater levels of initial investment than if pots could be made and replaced at will. As pottery is difficult to make during the winter, foragers may have produced pots during the warmer months in places removed from their eventual use. The additional investment required to make pots durable enough to survive transport would be further justified by the anticipated use time during the critical months of winter. It is also possible that foragers would manufacture pots in the same places they were eventually used, but this would depend on the timing of the winter aggregation and on the onset of cold weather, or alternatively on the scheduling of visits to the winter aggregation areas for pottery production during the warmer months. Either way, we expect the emphasis to be on high-investment pottery manufactured for longer and more reliable use throughout the winter.

In the winter aggregation scenario, we also expect to see several low-density occupation areas representing summer dispersal of groups. These summer camps would occasionally have pottery (either low- or high-investment types), but sometimes have none in accordance with the processing demands of the local resource base. As pottery is more easily produced in the summer, we expect presence of high-investment pottery at summer settlements to indicate production of vessels for winter use, for generalized cooking use, or as cached vessels for processing seasonally reliable, constrained resources. Low-investment pottery, on the other hand, may instead indicate the opportunistic processing of unanticipated, randomly encountered resources. This particular type of settlement pattern may be produced by groups with practices and cultural adaptations similar to those of mid-latitude foragers.

By contrast, we expect aggregation areas marked by (1) a lower ratio of pottery to lithics but (2) a higher proportion of low-investment pottery to be occupied during the summer (see "Summer Aggregation" in Figure 4). The lower ratio of pottery to lithics at summer aggregation areas reflects the diminished overall importance of pottery during the warmer part of the year. When pottery is present in summer aggregation areas, we expect most of it to be produced expediently for relatively immediate, short-term use. A smaller proportion of the ceramic assemblage will represent high-investment pots that were produced at these sites for eventual use at winter camps. We expect small, dispersed, low-density artifact scatters with ceramic assemblages that are dominated by high-investment pottery, to be winter residential camps. While the presence of high-investment pottery at these camps highlights the importance of degreasing bone to winter survival, we do not expect to see ceramics at all such locations, as many of these artifact scatters may represent hunting, butchering, or re-tooling locations rather than processing or cooking stations. Regions characterized by this kind of material record point to a settlement system defined by high residential mobility during the winter months and aggregation during the summer months, typified by the ethnographic "serial specialists" (Binford 1980).

These examples are not about the initial invention or adoption of pottery by mobile foraging people but instead reflect broad trends in decisions to make and use different kinds of pottery based on the costs and benefits of doing so under different subsistence-settlement strategies. This idealized case illustrates how the spatial distribution of two different kinds of pottery might reveal change in hunter-gatherer adaptive strategies.

\section{An Idealized Case of Herder Land-Use and the Distribution of Pottery}

A similar approach can be used to examine mobility and subsistence patterns among herding groups. Here we illustrate a case where the use of pottery by mobile herders changes with the addition of a novel technology (ceramics) to process a specific 
resource (dairy products). We maintain the same caveats as in the previous example and argue that the ratio of different kinds of pottery and the absolute abundance of pottery at sites can be used to infer patterns of resource use and seasonality by mobile herding groups.

Figure 5 depicts changes in the seasonal ceramic remains of mobile herders living in a marginal environment. In the first period of occupation ("Period I"), artifact scatters have similarly low numbers of sherds, though scatters in the west are composed of all high-investment pottery whereas those in the east are a mix of both high- and lowinvestment pottery. The limited distribution of lowinvestment pottery sherds among eastern "sites" is suggestive of a summer occupation when pots could be cheaply made for opportunistic harvesting and disposed of, whereas the lack of low-investment pottery at western sites suggests that they were occupied during winter months. More intensive use of high-investment pots for cooking and degreasing bone during the winter may also lead to a slightly higher number of these sherds at winter camps.

We expect that a novel development in pottery use, such as using special pots for dairying, will produce an identifiable pattern in the archaeological record. In "Period II," settlement patterns are identical to those of Period I, but the absolute number of sherds in the region has increased substantially. This increase is due to the high number of low-investment sherds at eastern sites. In contrast, the few sherds found at western sites are exclusively from high-investment pottery. Again, the proportions of low- and high-investment pots are consistent with winter occupation of the western camps and summer occupation of eastern camps. In Period II, changes in the abundance and proportion of low- and high-investment sherds through time highlight a shift in the use of pottery in this region. A substantial increase in low-investment sherds during Period II indicates that cheap ceramic vessels were being used with greater frequency to perform tasks that took place during the warmer part of the year. One very likely behavior this includes, given the context of the example, is dairying. Thus, the kind of change in ceramic assemblages seen in Figure 5 could indicate the adoption of new practices, such as dairying, or a switch from the use of organic to ceramic vessels for proessing milk products. In true archaeological settings, other lines of evidence such as residue analysis could be used to confirm this hypothesis.

Alterations to the seasonal cycle and subsistence of herders impact the patterns of ceramic distribution in distinct ways. If skin bags or other organic containers were used instead of expedient pots for dairying, low levels of high-investment sherds would appear at summer and especially winter camps for cooking and degreasing bone. If herders began caching higher-investment vessels at winter camp sites, high-investment sherds would become less common at summer sites resulting in more drastic differences between seasonal assemblages. Indeed, differences in the quality of (i.e., investment in) ceramics from winter and summer sites may lead culture historians to interpret these camp sites as manifestations of different archaeological "cultures."

With this idealized case, we present yet another way in which the logic of the tech investment model can further our understanding of past behavior. This example also reminds us to be cautious about equating technological investment or intensification with behavioral complexity; more complex social arrangements and economic entanglements may be answered best with less costly and seemingly more "simple" technology (contra Liu and Feng 2012). In this example, dairy processing (and perhaps all of the social developments that might attend it) is linked to the adoption of a cheaper technological form.

\section{Insights from the Technological Investment Model}

The tech investment model is a heuristic tool that clarifies the process of technological adoption by highlighting three basic variables that contribute to decision-making. Looking at the relationship between these essential variables - manufacture time, utility, and use time-provides insight on the abundance and distribution of ceramics through time and space under variable social and ecological conditions, namely mobility, marginality, and seasonality.

Current discussions of ceramic adoption pit functionalist explanations against political or ritual ones. Underlying this divide are simply two ways 

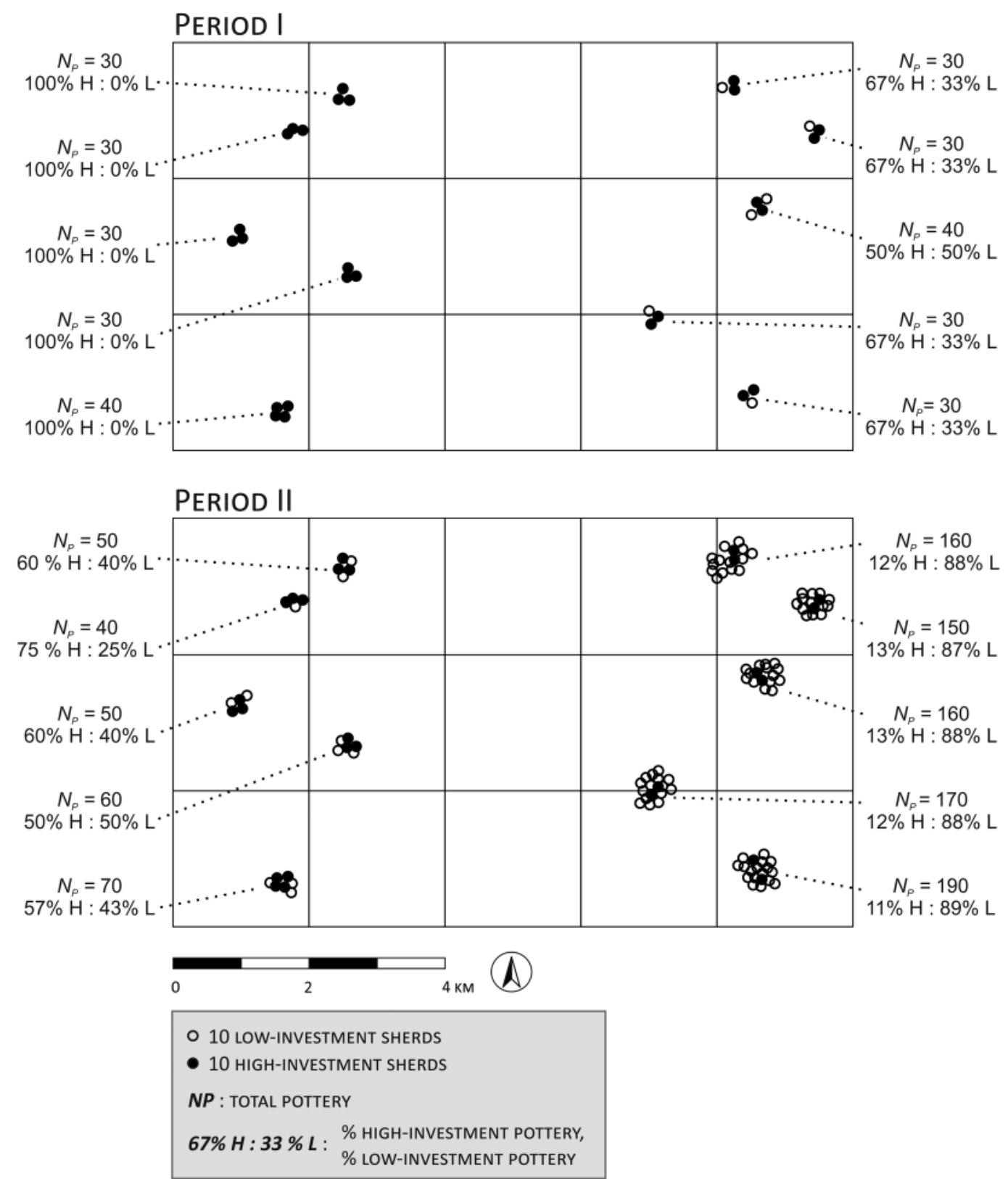

Figure 5. Idealized spatial distribution of low- and high-investment pottery in a marginal environment occupied by mobile herders. Differences in the proportions of high- and low-investment pottery and the absolute abundance of pottery through time reveal the seasonality of site occupation and a shift in resource use. Low-investment pottery is more abundant at eastern sites in Period I and in Period II, suggesting these camps were occupied during the summer. Lowinvestment pottery is also universally more abundant among Period II sites than Period I sites, suggesting a change in the cost-benefit attributes of the technology.

of calculating utility. While we have followed the convention of most optimization models to focus on energetic utility $(\mathrm{kcal} / \mathrm{hr})$, the tech investment model is not restricted to any single currency.
Cases where investment in pottery cannot be accounted for in terms of caloric utility may be instances in which returns are social or political (sensu Rocek 2013; Skibo et al. 2008). 
The tech investment model demonstrates that manufacturing time and use time are just as critical to technological adoption as utility. Manufacture time represents the immediate, or front-loaded, cost of technological adoption. The idealized cases of pottery investment we have presented here indicate that the relationship between environment and technological choice is quite complex, and that the decision to invest in technology is tempered by expectations for its use. We suggest that even in environments where raw materials are abundant and the manufacture of cheap but functional pots is possible, potters should choose to invest in wares that can be used in important subsistence tasks across longer periods of time. Seen from this perspective, the manufacturing process offers an opportunity for potters to reduce future uncertainties based on their experience of the lifespan of vessels and their anticipated cooking needs.

Although the tech investment model does not explicitly account for travel time, potters should account for this when they anticipate that their vessels will be transported often. Features such as thin walls, handles or lugs, higher firing temperatures, roughened exteriors, and fine, wellsorted temper make pots easier or safer to carry but require more effort to manufacture. The positive relationship between investment and mobility has been documented in the western Great Basin, among other regions (Eerkens 2003).

The model also clarifies the role of use time in technological choice. The decision to invest in a more or less expensive technology is informed by an individual's expectations of the future. Most literature that deals with pottery production focuses on the cost of manufacture, especially with regard to how it conflicts with a mobile lifestyle. However, the tech investment model highlights how under certain conditions, cheap and expensive technologies may be simultaneously viable, and that it is in anticipation of use time that users chose to invest in one or the other technology. Once expectations for future needs change, so too do decisions about how to invest in technology. Therefore, tracing changes in the nature of artifact assemblages can expose changes in human planning and reaction to their natural, social, and political environments.

A final advantage of the tech investment model is that it disentangles apparent contradictions in the literature of mobility and pottery. Pottery is alternatively considered to be fuel taxing (Brown 1989; Eerkens 2003, 2008) and fuel conserving (Bettinger et al. 1994; Nelson 2010). Similarly, pots are seen to simultaneously create (Arnold 1985; Stark 1995) and resolve (Crown and Wills 1995; Garraty 2011) scheduling conflicts. The tech investment model reveals that these characteristics are not paradoxical at all, but rather refer to different ways of organizing and applying the model. References to the fuel-taxing or schedulelimiting nature of pottery are focused on its manufacturing costs, while references to pottery's fuelconserving and schedule-freeing qualities are based on observations of utility. By distinguishing between these elements, we can clarify why pottery was used-whether it reduced production costs, maximized utility gains, or conserved key resources - and the kinds of problems that ceramic technology was intended to solve.

Taken together, these three variables further archaeological understanding of the material record. This logic can be applied to idealized cases, as we demonstrate in this paper, or coupled with experimental study and archaeological datasets to reveal decision-making related to expected needs, such as the need to boil bones in the winter, and new kinds of behaviors, such as the adoption of dairying among herders or a switch to a pattern of winter mobility among foragers. This novel approach to pottery analysis complements modern lithic analysis, and expands the analytical toolkit archaeologists have at their disposal to interpret the often ephemeral occupational remains of mobile groups.

We are not the first to make these observations about pottery investment and use among mobile groups. Previous publications have analyzed variation in ceramic technology among residentially mobile, logistically mobile, and sedentary groups in greater depth than we have here. To this point, we add that the same groups may invest differently in pottery depending on the kind of task being performed. However, our larger contribution to this field is to advocate that future work focus on identifying organizing principles of technological investment rather than refining typologies of quintessentially "mobile" pottery. By using even simple models, as we do here, we can understand technological change at the scale of the user rather than as a phenomenon tied to broad economic traditions. 
Acknowledgments. Support for the fieldwork that fostered these ideas was provided by NSF grant BCS-1236939, the University of Pittsburgh Department of Anthropology, and the Luce Foundation. We are thankful to Liz Arkush, Maria Lis Baiocchi, Igor Chechushkov, Lauren Herckis, Matt Kesterke, Pat Mullins, and Ljiljana Pantovic for providing invaluable feedback on an earlier draft of this paper, and to the Editor and five anonymous reviewers for their constructive and insightful comments. Finally, we are grateful to Gabriela Cervantes for translating our abstract into Spanish and to Antonio Rodríguez-Hidalgo for checking it.

\section{References Cited}

Anderson, M. Kat

1999 The Fire, Pruning, and Coppice Management of Temperate Ecosystems for Basketry Material by California Indian Tribes. Human Ecology 27:79-113.

Andrefsky, William-Jr.

1994 Raw-Material Availability and the Organization of Technology. American Antiquity 59:21-34.

Arnold, Dean E.

1985 Ceramic Theory and Cultural Process. Cambridge University Press, Cambridge.

Barnett, William K., and John W. Hoopes (editors)

1995 The Emergence of Pottery: Technology and Innovation in Ancient Societies. Smithsonian Institution, Washington, D.C.

Beck, Margaret E.

2009 Residential Mobility and Ceramic Exchange: Ethnography and Archaeological Implications. Journal of Archaeological Method and Theory 16:320-356.

Bettinger, Robert L., David B. Madsen, and Robert G. Elston 1994 Prehistoric Settlement Categories and Settlement Systems in the Alashan Desert of Inner Mongolia, PRC. Journal of Anthropological Archaeology 13:74-101.

Bettinger, Robert L., Christopher Morgan, and Loukas Barton 2015 The North China Nanolithic. In Lithic Technological Systems and Evolutionary Theory, edited by Nathan Goodale and William Andrefsky, pp. 100-116. Cambridge University, Cambridge.

Bettinger, Robert L., Bruce Winterhalder, and Richard McElreath 2006 A Simple Model of Technological Intensification. Journal of Archaeological Science 33:538-545.

Binford, Lewis R.

1978 Nunamiut Ethnoarchaeology. Academic Press, New York.

1979 Organization and Formation Processes: Looking at Curated Technologies. Journal of Anthropological Research 35:255-273.

1980 Willow Smoke and Dog's Tails: Hunter-Gatherer Settlement Systems and Archaeological Site Formation. American Antiquity 54:4-20.

Blackman, James M., Sophie Mery, and Rita P. Wright

1989 Production and Exchange of Ceramics on the Oman Peninsula from the Perspective of Hili. Journal of Field Archaeology 16:61-77.

Boar Elisabetta, Xiang Wu, Jiaorong Yuan, Ofer BarYosef, Vikki Chu, Yan Pan, Kexin Liu, David Cohen, Tianlong Jiao, Shuicheng Li, Haibin Gu, Paul Goldberg, and Steve Weiner

2009 Radiocarbon Dating of Charcoal and Bone Collagen Associated with Early Pottery at Yuchanyan Cave, Hunan Province, China. Proceedings of the National Academy of Sciences 106 (24):9595-9600.
Braun, David P.

1983 Pots as Tools. In Archaeological Hammers and Theories, edited by Arthur Keene and James Moore, pp. 107-134. Academic, New York.

Bright, Jason, Andrew Ugan, and Lori Hunsaker,

2002 Effect of Handling Time on Subsistence Technology. World Archaeology 34:164-181.

Brown, Jame A

1989 The Beginnings of Pottery as an Economic Process. In What's New? A Closer Look at the Process of Innovation, edited by Sander van der Leeuw and Robin Torrence, pp. 203-224. Unwin Hyman, London.

Charnov, Eric L.

1976 Optimal Foraging: The Marginal Value Theorem. Theoretical Population Biology 9:129-136.

Clark, John E., and Michael Blake

1994 The Power of Prestige: Competitive Generosity and the Emergence of Rank Societies in Lowland Mesoamerica. In Factional Competition and Political Development in the New World, edited by Elizabeth M. Brumfiel and John W. Fox, pp. 17-30. Cambridge University, Cambridge.

Copley, M.S., R. Berstan, S.N. Dudd, S. Aillaud, A.J. Mukherjee, and V. Straker

2005 Processing of Milk Products in Pottery Vessels through British Prehistory. Antiquity 79:895-908.

Craig, O.E., H. Saul, A. Lucquin, Y. Nishida, K. Taché, L. Clarke, A. Thompson, D.T. Altoft, J. Uchiyama, M. Ajimoto., K. Gibbs, S. Isaksson, C.P. Heron, and P. Jordan

2013 Earliest Evidence for the Use of Pottery. Nature 496:351-354

Crown, Patricia L., and Wirt H. Wills

1995 The Origins of Southwestern Ceramic Containers: Women's Time Allocation and Economic Intensification. Journal of Anthropological Research 51:173-186.

Dietz, Jane M., and John W. Erdman

1989 Effects of Thermal Processing upon Vitamins and Proteins in Foods. Nutrition Today 24:6-15.

Driver, Harold E., and William C. Massey

1957 Comparative Studies of North American Indians, Part 2 Transactions of the American Philosophical Society, New Series, vol. 47. American Philosophical Society, Philadelphia.

Dunne, Julie, Richard P. Evershed, Mélanie Salque, Lucy Cramp, Silvia Bruni, Kathleen Ryan, Stefano Biagetti, and Savino di Lernia

2012 First Dairying in Green Saharan Africa in the Fifth Millennium BC. Nature 486 (7403):390-394.

Eerkens, Jelmer W.

2003 Residential Mobility and Pottery Use in the Western Great Basin. Current Anthropology 44:728-741.

2004 Privatization, Small-Seed Intensification, and the Origins of Pottery in the Western Great Basin. American Antiquity 69:653-670.

2008 Nomadic Potters: Relationships between Ceramic Technologies and Mobility Strategies. In The Archaeology of Mobility: Old World and New World Nomadism, edited by Hans Barnard and Willeke Wendrich, pp. 307-326. Cotsen Institute, Los Angeles.

2011 Pot Conveyance, Design Characteristics, and Precontact Adaptations to Arid Environments. In Perspectives on Prehistoric Trade and Exchange in California and the Great Basin, edited by Richard E. Hughes, pp. 135-147. University of Utah, Salt Lake City.

Farrell, Thomas F.G., Peter Jordan, Katrine Taché, Alexandre Lucquin, Kevin Gibbs, Ana Jorge, Kate Britton, Oliver E. Craig, and Rick Knecht

2014 Specialized Processing of Aquatic Resources in Prehistoric Alaskan Pottery? A Lipid-Residue Analysis of 
Ceramic Sherds from the Thule-Period Site of Nunalleq, Alaska. Arctic Anthropology 51:86-100.

Feinman, Gary M., Steadman Upham, and Kent G. Lightfoot 1981 The Production Step Measure: An Ordinal Index of Labor Input in Ceramic Manufacture. American Antiquity 46:871-884.

Frink,_Lisa, and Karen G. Harry

2008 The Beauty of "Ugly" Eskimo Cooking Pots. American Antiquity 73:103-120.

Garraty, Christopher P.

2011 The Origins of Pottery as a Practical Domestic Technology: Evidence from the Middle Queen Creek Area, Arizona Journal of Anthropological Archaeology 30:220-234.

Garvey, Raven

2015 A Model of Lithic Raw Material Procurement. In Lithic Technological Systems and Evolutionary Theory, edited by Nathan Goodale and William Andrefsky, pp. 156-171. Cambridge University Press, Cambridge.

Gibbs, Kevin

2012 Not Meant to Last: Mobility and Disposable Pottery. Documenta Praehistorica 39:83-93.

Gibbs, Kevin, and Peter Jordan

2013 Bridging the Boreal Forest: Siberian Archaeology and the Emergence of Pottery among Prehistoric HunterGatherers of Northern Eurasia. Siberica 12(1):1-38.

Goodyear, Albert C.

1988 On the Study of Technological Change. Current Anthropology 29:320-323.

Goulder, Jill

2010 Administrators' Bread: An Experiment-Based ReAssessment of the Functional and Cultural Role of the Uruk Bevel-Rim Bowl. Antiquity 84:351-362.

Hall, Mark, William Honeychurch, Joshua Wright, Zagd Batsaikhan, and Luvsanvandan Bilegt

1999 Chemical Analyses of Prehistoric Mongolian Pottery. Arctic Anthropology 36:133-150.

Harry, Karen, and Liam Frink

2009 The Arctic Cooking Pot: Why Was It Adopted? American Anthropologist 111:330-343.

Hayden, Brian

1995 The Emergence of Prestige Technologies and Pottery. In The Emergence of Pottery: Technology and Innovation in Ancient Societies, edited by William K. Barnett and John W. Hoopes, pp. 257-265. Smithsonian Institution, Washington, D.C.

Hoopes, John W.

1995 Interaction in Hunting and Gathering Societies as a Context for the Emergence of Pottery in the Central American Isthmus. In The Emergence of Pottery: Technology and Innovation in Ancient Societies, edited by William K. Barnett and John W. Hoopes, pp. 185-198. Smithsonian Institution, Washington, D.C

Ikawa-Smith, Fumiko

1976 On Ceramic Technology in East Asia. Current Anthropology 17:513-515.

Jordan, Peter, and Marek Zvelebil (eds)

2009 Ceramics before Farming: The Dispersal of Pottery among Prehistoric Eurasian Hunter-Gatherers. Left Coast, Walnut Creek, California.

Jorge, A., M.I. Dias, and P.M. Day

2013 Plain Pottery and Social Landscapes: Reinterpreting the Significance of Ceramic Provenience in the Neolithic. Archaeometry 55:825-851.

Keally, Charles T, and Igor Y. Shewkomud

2004 Chronology of the Beginning of Pottery Manufacture in East Asia. Radiocarbon 46: 345-351.
Lewthwaite, James G.

1982 Acorns for the Ancestors: The Prehistoric Exploitation of Woodland in the West Mediterranean. In Archaeological Aspects of Woodland Ecology, edited by Martin Bell and Susan Limbrey, pp. 217-230. BAR International Series 146. British Archaeological Reports, Oxford.

Liu, Fenggui, and Zhaodong Feng

2012 A Dramatic Climatic Transition at 4000 cal. yr BP and Its Cultural Responses in Chinese Cultural Domains. The Holocene 22:1181-1197.

Nelson, Kit

2010 Environment, Cooking Strategies and Containers. Journal of Anthropological Archaeology 29:238-247.

Outram, Alan K., Natalie A. Stear, Robin Bendrey, Sandra Olsen, Alexei Kasparov, Victor Zailbert, Nick Thorpe, and Richard P. Evershed

2009 The Earliest Horse Harnessing and Milking. Science 323:1332-1335.

Reid, Kenneth C

1989 A Materials Science Perspective on Hunter-Gatherer Pottery. In Pottery Technology: Ideas and Approaches, edited by Gordon Bronitsky, pp. 167-180. Westview, Boulder, Colorado.

Rice, Prudence M.

1996 Recent Ceramic Analysis: 1. Function, Style, and Origins. Journal of Archaeological Research 4:133-163.

1999 On the Origins of Pottery Jown of Archaged Method and Theory 6:1-54.

2015 Pottery Analysis:A Sourcebook. University of Chicago, Chicago.

Rocek, Thomas R.

2013 Why Not Pottery? A Comparative Approach to the Variables Underlying the Adoption (or Non-Adoption) of Ceramics. Anthropologie 1/2: 231-242.

Sassaman, Kenneth E.

1993 Early Pottery in the Southeast: Tradition and Innovation in Cooking Technology. University of Alabama, Tuscaloosa.

Simms, Steven R., Jason R. Bright, and Andrew Ugan 1997 Plain-Ware Ceramics and Residential Mobility: A Case Study from the Great Basin. Journal of Archaeological Science 24:779-792.

Skibo, James.M., and Gary M. Feinman (editors)

1999 Pottery and People: A Dynamic Interaction. University of Utah, Salt Lake City.

Skibo, James M., Michael B. Schiffer, and Eric Blinman

2008 The Origins of Pottery on the Colorado Plateau. In People and Things: A Behavioral Approach to Material Culture, edited by James Skibo and Michael B. Schiffer, pp. 37-52. Springer, New York.

Skibo, James M., Michael B. Schiffer, and Kenneth C. Reid 1989 Organic-Tempered Pottery: An Experimental Study. American Antiquity 54:122-146.

Speth,John D.

2015 When Did Humans Learn to Boil? PaleoAnthropology 2015:54-67.

Speth, John D., and Katherine A. Spielmann

1983 Energy Source, Protein Metabolism, and HunterGatherer Subsistence Strategies. Journal of Anthropological Archaeology 2:1-31.

\section{Stark Miriam T}

1995 Economic Intensification and Ceramic Specialization in the Philippines: A View from Kalinga. Research in Economic Anthropology 16:179-226.

Taché, Karine, and Oliver E. Craig

2015 Cooperative Harvesting of Aquatic Resources and the Beginning of Pottery Production in North-Eastern North America. Antiquity 89:177-190. 
Thoms, Alston V.

2009 Rocks of Ages: Propagation of Hot-Rock Cookery in Western North America. Journal of Archaeological Science 36: 573-591.

Ugan, Andrew, Jason Bright, and Alan Rogers

2003 When is Technology Worth the Trouble? Journal of Archaeological Science 30:1315-132.

Ullah_I IT, Ian Kuijt, and Jab Freeman

2015 Toward a Theory of Punctuated Subsistence Change. Proceedings of the National Academy of Science 112(31):9579-9584.

Vitelli, Karen D.

1989 Were Pots First Made For Food? Doubts from Franchthi. World Archaeology 21:17-29.

Wandsnider, LuAnn

1997 The Roasted and the Boiled: Food Consumption and Heat Treatment with Special Emphasis on Pit-Hearth Cooking. Journal of Anthropological Archaeology 16:148.
Wu, Xiaohong, Chi Zhang, Paul Goldberg, David Cohen, Yan Pan, Trina Arpin, and Ofer Bar-Yosef

2012 Early Pottery at 20,000 Years Ago in Xianrendong Cave, China. Science 336:1696-1700.

Yi, Mingjie, Loukas Barton, Christopher Morgan, Decheng Liu, Fuyou Chen, Yue Zhang, Shuwen Pei, Ying Guan, Huimin Wang, Xing Gao, and Robert L. Bettinger

2013 Microblade Technology and the Rise of Serial Specialists in North-Central China. Journal of Anthropological Archaeology 32:212-223.

Submitted April 11, 2016; Revised June 19, 2016; Accepted June 25, 2016 